\title{
Early life history of the Caribbean coral Orbicella faveolata (Scleractinia: Merulinidae)
}

\author{
Elvira M. Alvarado-Chacon ${ }^{1 *}$, Luis A. Gómez-Lemos ${ }^{2}$, Nireth P. Sierra-Sabalza ${ }^{1}$, \\ Ana M. Hernández-Chamorro ${ }^{1}$, Juan P. Lozano-Peña ${ }^{1}$, Camilo A. Valcárcel-Castellanos ${ }^{3}$, \\ Valeria Pizarro $^{4}$, Rocío García-Urueña ${ }^{2}$, Juan C. Zárate-Arévalo ${ }^{5} \&$ Jaime A. Rojas ${ }^{5}$ \\ 1. Universidad de Bogotá Jorge Tadeo Lozano, Bogotá Colombia; ealvaradochacon@gmail.com, \\ elvira.alvarado@utadeo.edu.co,nirethsierra@gmail.com, ana.hernandezc@utadeo.edu.co, \\ juanp.lozanop@utadeo.edu.co \\ 2. Universidad del Magdalena, Santa Marta, Colombia; lgomezl@unimagdalena.edu.co, garciarociop@gmail.com \\ 3. Parque Nacional Natural Los Corales del Rosario y de San Bernardo, Cartagena, Colombia; \\ kmilovalcarcel@gmail.com \\ 4. Fundación Ecomares; valeria.pizarro@ecomares.org \\ 5. CEINER, Oceanario Islas del Rosario, Colombia; juanc.zaratea@utadeo.edu.co, rojasruizjaime@gmail.com \\ * Correspondence
}

Received 21-II-2020. C Corrected 30-VII-2020. Accepted 02-IX-2020.

\begin{abstract}
Introduction: Rehabilitation of hermatypic coral species that have declined in the Caribbean in recent decades is a priority. Production of sexual recruits is considered the best restoration method to aid affected populations. Objective: To gain knowledge of early life stages of Orbicella faveolata and to enhance production of new sexual recruits. Methods: Gamete bundles from the coral species $O$. faveolata were collected over two years (2018 and 2019) from Los Corales del Rosario y de San Bernardo Natural National Park, Cartagena, Colombia. Assisted fertilization, larval rearing, settlement (onto crustose coralline algae, CCA) and post settlement survival in laboratory conditions were monitored. Results: Embryonic and larval development were documented over 55 hours after the first cleavage, when larvae were fully developed and started pre-settlement behavior. Settlement began 7 days after first cleavage and after 37 days polyps had acquired zooxanthellae. Larval settlement was higher on Lythophyllum congestum and Titanoderma prototypum than in response to Porolithon pachydermum, Neogoniolithon sp., Hydrolithon sp., and Lythophyllum sp. Larvae did not settle on dead coral or on the negative control (sterilized seawater). After the first week post settlement survival was $59 \%$ amongst $O$. faveolata recruits. During the second week, survival dropped to $42 \%$, and was further reduced to 0 $\%$ at the end of the third week. Conclusions: $O$. faveolata larvae require cues from certain CCA species to settle, they do not settle in absence of CCA. Increased larvae availability is possible through assisted fertilization in the laboratory, however, due to the high mortality in early post-settlement phases, additional research needs to be conducted in order to scale up larvae production and improve understanding of the cues that enhance settlement and the factors which cause post-settlement mortality.
\end{abstract}

Key words: spawning; assisted fertilization; embryogenesis; larval settlement; post-settlement survival; CCA.

Alvarado-Chacon, E.M., Gómez-Lemos, L.A., Sierra-Sabalza, N.P., Hernández-Chamorro, A.M., Lozano-Peña, J.P., Valcárcel-Castellanos, C.A., Pizarro, V., García-Ureña, R., Zárate-Arévalo, J.C., \& Rojas, J.A. (2020). Early life history of the Caribbean coral Orbicella faveolata (Scleractinia: Merulinidae). Revista de Biología Tropical, 68(4), $1262-1274$.

Scleractinian reef-building corals are structural species on coral reefs, providing the primary framework and the three-dimensional complexity of reefs, which make them essential habitats for thousands of associated species (Harrison, 2011). However, approximately 
$75 \%$ of the world's coral reefs are threatened by one or more local threats (e.g., overfishing, coastal development, pollution, thermal stress) linked to the widespread weakening and mortality of corals due to mass coral bleaching (Burke, Reytar, Spalding, \& Perry, 2011). Reef-building corals are in decline worldwide, with a corresponding reduction of live coral cover resulting in a loss of architectural complexity (Bozec, Alvarez-Filip, \& Mumby, 2014). Depending on local conditions in tropical coastal areas, corals can recruit, grow, maintain colony integrity, suffer partial mortality or die and disappear completely. Such ecological processes will shape the characteristics of the coral subpopulation (Bak \& Meesters, 1999). Coral species and their recruits in the Caribbean are decreasing in abundance and cover, with only few juveniles of those species being found (Acropora cervicornis, A. palmata, Orbicella annularis, O. faveolata) (Hughes \& Tanner, 2000; Edmunds \& Elahi, 2007; Williams, Miller, \& Kramer, 2008; Edmunds et al., 2015). A study conducted in Curaçao reported a decline of $54.7 \%$ in juvenile coral abundance and a shift in species composition between 1975 and 2005 (Vermeij, Bakker, Hal, Van Der, \& Bak, 2011). As a result, the majority of coral colonies occur in the larger size classes, which is the main characteristic of populations on degraded reefs (Vermeij, Frade, Jacinto, Debrot, \& Bak, 2007). Rehabilitating populations of Caribbean coral species that have declined in recent decades and promoting recruitment of these species to reefs have become management priorities throughout the region (Chamberland, Snowden, Marhaver, Petersen, \& Vermeij, 2016).

Currently, efforts are being made to promote the protection, recovery and rehabilitation of coral species by sexually propagating broadcast spawning corals (Omori, 2005; Okamoto, Nojima, Fujiwara, \& Furushima, 2008; Guest et al., 2010; Nakamura, Ohki, Suzuki, \& Sakai, 2011; Guest, Baria, Gomez, Heyward, \& Edwards, 2014; among others), which has gained popularity as an approach for reef restoration (Chamberland et al., 2017). Larval availability, successful settlement, and postsettlement survival and growth are all necessary for the addition of new coral individuals to a reef, and ultimately the maintenance and recovery of coral reef ecosystems. Successful recruitment requires the survival of coral offspring through sequential life history stages (Ritson-Williams et al., 2009). Thus, using a laboratory environment to rear larvae of ecologically important coral species is a necessary method to aid in the recovery of degraded populations besides yielding new genotypes capable of coping with the anomalous conditions on Caribbean reefs (Chamberland et al., 2016).

Although our understanding on early life history stages of corals and their recruitment to reefs is continuing to grow (Chamberland et al., 2017; Calle-Triviño, Cortés-Useche, Sellares-Blasco, \& Arias-Gonzáles, 2018), little information exists on the earliest life stages of many Caribbean coral species. Out of 1500 recognized coral species, aspects of sexual reproduction have been studied in only 444 species, the majority of these being shallow water, zooxanthellate, hermatypic coral species (Harrison, 2011). Information on species' reproductive traits (i.e., reproductive mode, timing of gametogenesis, and fecundity) is available for nearly $50 \%$ of all Caribbean coral species, but very little is known about their early life stages such as embryonic development, larval settlement and post-settlement survival (Chamberland et al., 2016).

Orbicella faveolata is one of the most important species in the Caribbean due to its wide distribution and complex reef bioconstruction. In the Natural National Park Los Corales del Rosario y de San Bernardo (PNNCRSB), Colombia, this species is the most abundant with $29.9 \%$ relative cover (Alvarado, Pizarro, \& Sarmiento-Segura, 2011). This "robust" species (Lin et al., 2014) is hermaphroditic, with an annual gametogenic cycle (Van Veghel \& Bak, 1994). Gamete bundles are released between September and October, six and seven days after the full moon [90 and $10 \%$ respectively (Sánchez et al., 1999)]. Notwithstanding its participation in the annual multispecies 
spawning event, presents low recruitment (0.30.4 juveniles $\mathrm{m}^{-2}$, Miller, Weil, \& Szmant, 2000), being abundant as adult colonies, but with less than $5 \%$ of relative abundance of juveniles in the study zone (Henao, 2012). Additionally, $O$. faveolata is frequently affected by bleaching and disease in suboptimal conditions due to high temperatures, low salinity, high nutrients, and sedimentation from terrestrial runoff (Restrepo \& Alvarado, 2011) which mainly occur during spawning season.

There is a need to implement strategies for the repopulation of this key species through sexual reproduction, generating mechanisms to assist the fertilization and recruitment of this species in order to increase genetic diversity and survival, promoting the potential for more resilient reefs (Alcolado, Valle, Claro, \& Hernández-Zanuy, 2016). With the aim of contributing to the knowledge of the earliest life stages of $O$. faveolata, and to enhance production of new sexual recruits, we collected and fertilized gametes ex situ to document embryogenesis, settlement patterns and early post-settlement survival at PNNCRSB, Colombian Caribbean.

\section{MATERIALS AND METHODS}

Study site: This study was carried out at the Natural National Park Los Corales del Rosario y de San Bernardo (PNNCRSB), Colombia, in the Southern Caribbean Sea. Spawning observation and gamete collection was conducted at

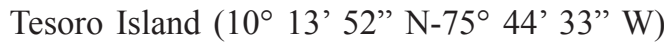
in 2018, and at Isla Grande Norte in three sites (Fiesta: $10^{\circ} 11^{\prime}$ 9" N-75'43' 41" W, Botellas: $10^{\circ} 11^{\prime} 4{ }^{\prime \prime} \mathrm{N}-75^{\circ} 43^{\prime}$ 44" $\mathrm{W}$ and Ministerio: $10^{\circ} 11^{\prime} 1$ ' $\mathrm{N}-75^{\circ} 43^{\prime} 53^{\prime}$ ' $\mathrm{W}$, in 2019). Ocean circulation in the area is dominated by the Caribbean Current due to the Northeast Alisios Tradewinds. Depending on the season the area shows differences in water quality due to river input from Magdalena River through Canal del Dique watercourse (Restrepo \& Kjerfve, 2000). Turbid plumes are more prominent in rainy season (May-July; September-November) and hit coral reefs through Barbacoas Bay. During dry season (January-April) turbid plumes hit coral reefs through Cartagena Bay (Restrepo, Park, Aquino, \& Latrubesse, 2016), carrying not only sediments, but also nutrient inputs and low salinity waters (Restrepo \& Alvarado, 2011). In addition to those threats, anthropogenic activities such as construction, boat traffic, overfishing, coral extraction, and SCUBA diving (Alvarado, Duque, Florez, \& Ramírez, 1986), as well as natural perturbations such as bleaching, macroalgae overgrowth, predation, and diseases have been reported as causes of the decline in coral cover (Solano, Navas, \& Moreno-Forero, 1993; Diaz et al., 2000; Garzón-Ferreira, Rodriguez-Ramírez, Bejarano-Chavarro, Navas-Camacho, \& Reyes-Nivia, 2001). Coral cover, although low (22-23.5 \%, NavasCamacho, Gómez-Campo, Vega-Sequeda, \& López-Londoño, 2009) is represented mainly by Orbicella faveolata, Porites astreoides and Agaricia tenuifolia (Alvarado et al., 2011).

\section{Collection of gametes and assisted fer-} tilization: Over the course of two years (2018 and 2019), six days after the full moon in September, gamete bundles were collected from 6 and 21 O. faveolata colonies, respectively, using $50 \mathrm{ml}$ falcon tubes placed on top of cone shaped nets that were laid over parts of the colonies. These bundles were transported to the CEINER laboratory ( $30 \mathrm{~min}$ boat ride).

In 2018 gamete bundles were mixed in three fat separators of one liter pouring bundles from three different colonies in each, while in 2019 these were mixed in six fat separators, using 3-4 parent colonies of different sites. Sperm concentration was adjusted by adding sterilized seawater. Embryogenesis procedures followed standard larval culture (Marhaver, Chamberland, \& Fogarty, 2017). Fertilization was confirmed under a dissecting microscope after $2 \mathrm{~h}$, and embryos were rinsed several times with sterilized seawater (autoclaved for $1 \mathrm{~h}$ ) to remove the excess of sperm to avoid polyspermy. The embryos were kept in sterilized seawater in transparent one liter polystyrene containers. In each of the 44 containers, approximately 1000 embryos were raised. 
Water in the containers was cleaned with Pasteur pipettes from second cleavage to gastrula. Thereafter, water was changed every $6 \mathrm{~h}$ to prevent bacterial outbreaks. The embryo culture was kept at $28^{\circ} \mathrm{C}$ (the average sea surface temperature in the area during the study).

Embryogenesis, larval rearing, and settlement competence: Embryo development was documented photographically under a dissecting microscope at different developmental stages in both years. In 2018, follow-up was done every hour for the first $24 \mathrm{~h}$ and every 12 $\mathrm{h}$ from there on, until pre-settlement. In 2019 embryogenesis was assessed every $30 \mathrm{~min}$ for the first day, every hour for the second day, and every $3 \mathrm{~h}$ for the third day when pre-settlement behavior was observed. In 2018, in order to know if larvae were competent to settle, i.e., attach and metamorphose (Heyward \& Negri, 1999), competence tests were performed by placing 3 small individual fragments $\left(1 \mathrm{~cm}^{2}\right)$ of the crustose coralline algae (CCA) species Titanoderma prototypum in multi-well plates (Nest ${ }^{\circledR)}$ ). 10 larvae were added in each well in a ratio of 1 larva per $\mathrm{ml}$ and allowed to settle for $24 \mathrm{~h}$ as defined by Gómez-Lemos, Doropoulos, Bayraktarov, and Díaz-Pulido (2018). Once larvae attached and underwent metamorphosis, they were considered competent to run the settlement assay. Larvae became competent 7 days after the assisted fertilization took place.

Settlement of larvae: Settlement assays were conducted in September 2018 in order to identify which CCA species induced the settlement of $O$. faveolata. We collected CCA from the reef using hammer and chisel (between 2 and $8 \mathrm{~m}$ depth by SCUBA diving) immediately transported to the laboratory at CEINER, where they were maintained in flow-through tanks until experimental onset. $O$. faveolata larvae were randomly selected and added to experimental containers $(20 \mathrm{ml}$ cell culture wells). 20 larvae were added to each experimental container, with 6 replicate containers per treatment. There were 8 treatments consisting of 6 different CCA species
(Lithophyllum congestum, Titanoderma prototypum, Porolithon pachydermum, Neogoniolithon sp., Hydrolithon sp., Lithophyllum sp.), one negative control (the seawater was sterilized in an autoclave for $1 \mathrm{~h}$ ) and one dead coral treatment. CCA species identification was confirmed under the microscope using anatomical features such as thallus organization, cell connections, trichocytes fields and reproductive structures (Taylor, 1960; Littler \& Littler, 2000; Farr, Broom, Hart, Neill, \& Nelson, 2009). The dead coral treatment consisted in fragments of naturally biofilmed coral rubble without macroscopic epibionts; fragments were collected in the same place where CCA were found. All fragments of live CCA and dead coral used in the settlement assays measured 1 $\mathrm{cm}^{2}$. Autoclaved seawater in the experimental containers was changed daily and any dead larvae were removed. A final scoring of settled (on live CCA surface, under the skeleton or on the container walls and bottom), swimming and dead larvae, was conducted at the end of the 48 hours of experimental period.

Post-settlement survival: To estimate the survival of $O$. faveolata settlers under controlled conditions, ceramic tiles were conditioned on coral rubble at $2 \mathrm{~m}$ depth for 1 year. The tiles were mainly colonized by filamentous algae $(19 \pm 5 \%)$, CCA $(13 \pm 3 \%)$, and other organisms ( $7 \pm 3 \%$ such as polychaetes, ascidians and bryozoans); the remaining $61 \pm 9 \%$ (mean $\pm \mathrm{SD}$ ) corresponded to bare substrate. The abundance of benthic organisms on the tiles was estimated with photographs using the software ImageJ. The conditioned tiles (21) were placed in $1 \mathrm{~L}$ polystyrene containers with sterilized seawater and 25 competent larvae were added in each container. We relocated 21 settlement tiles each having $6 \pm 5($ mean $\pm \mathrm{SD})$ 3 -week-old-settlers to the outdoor aquarium facilities at CEINER, where they were kept in a $1000 \mathrm{~L}$ flow-through tank. Prior to relocation, the position of each settler on the tiles was registered using a dissecting microscope, in order to find the individual settlers more easily later. The tiles were revisited every second day 

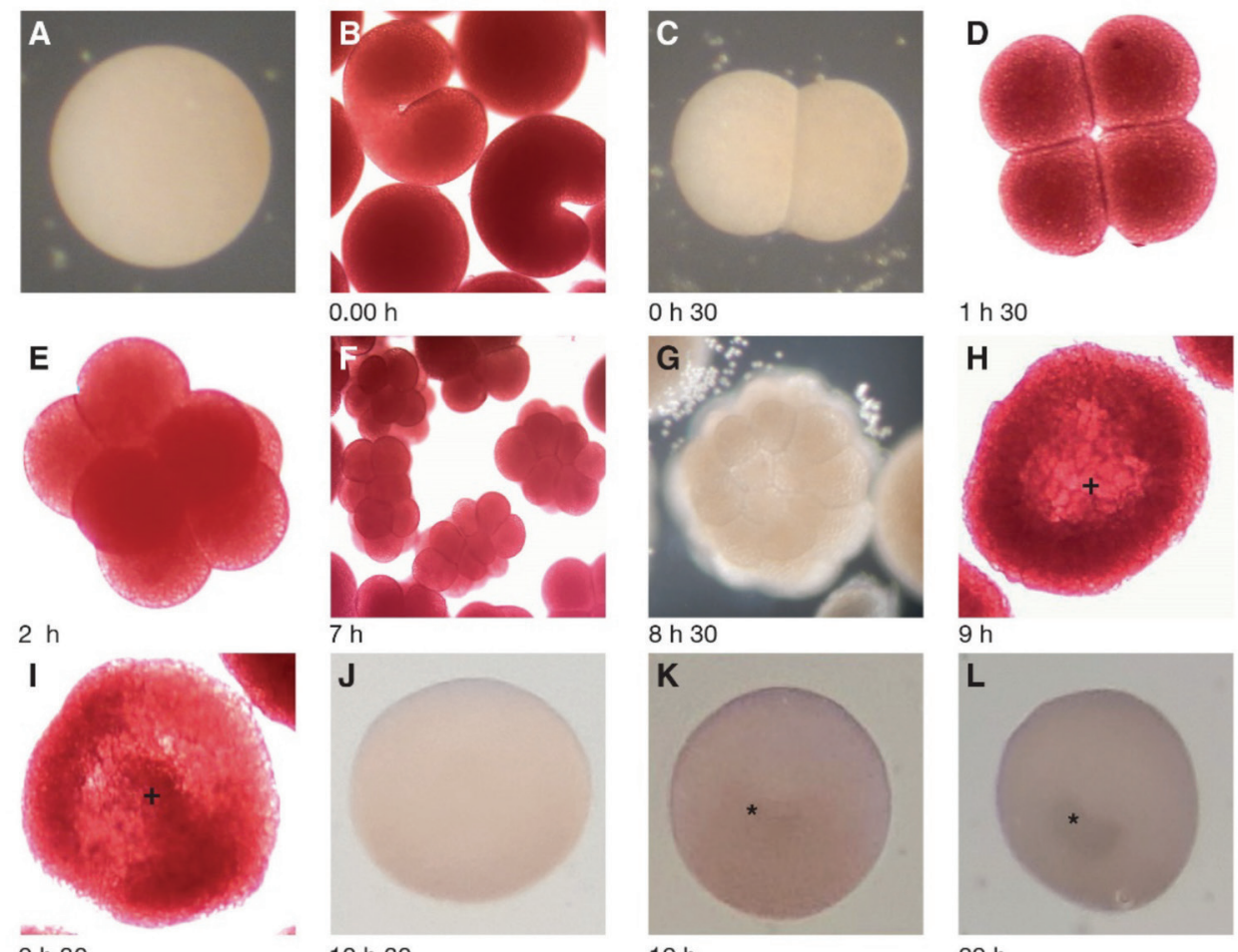

$9 \mathrm{~h}$
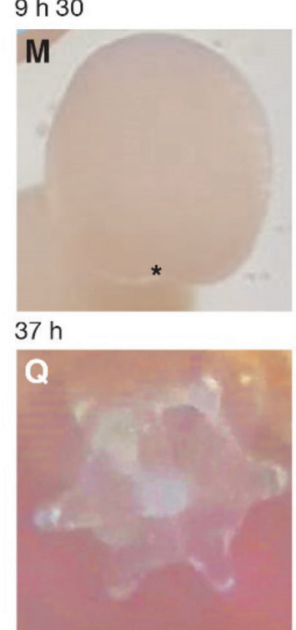

$10 \mathrm{~h} 30$

$19 \mathrm{~h}$
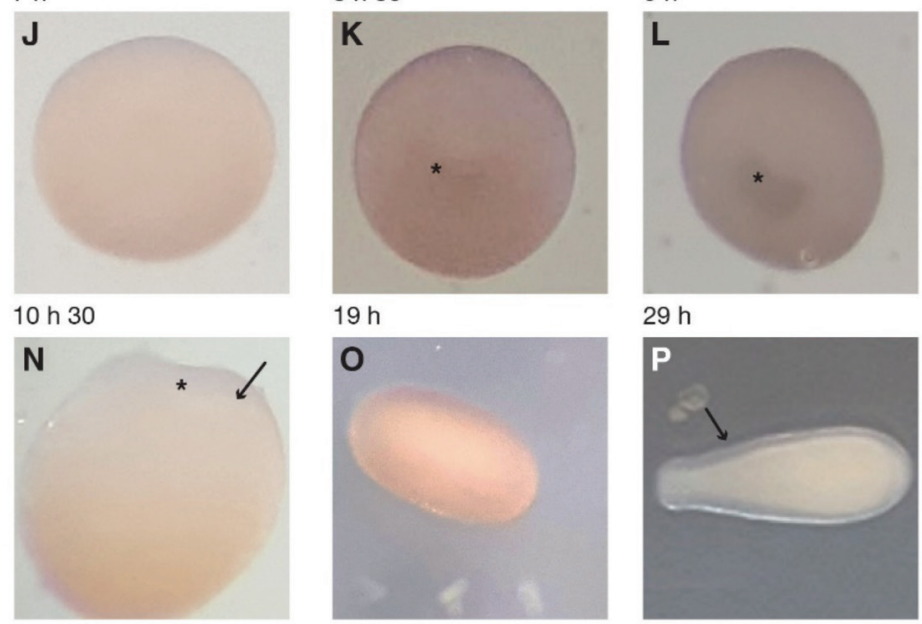

$41 \mathrm{~h}$
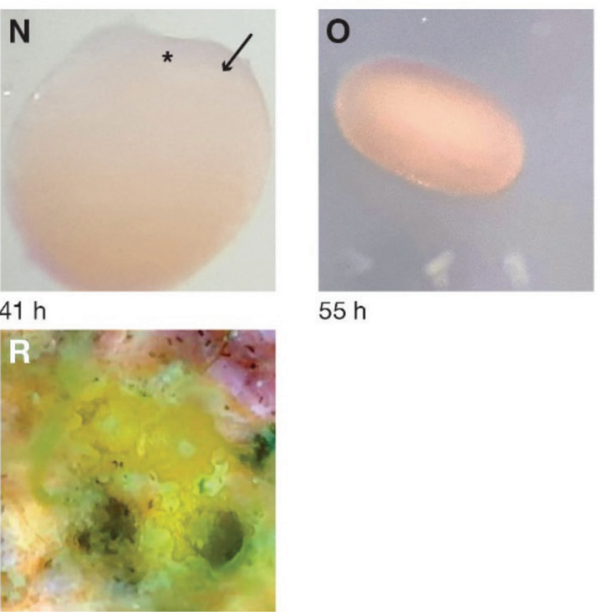

$55 \mathrm{~h}$

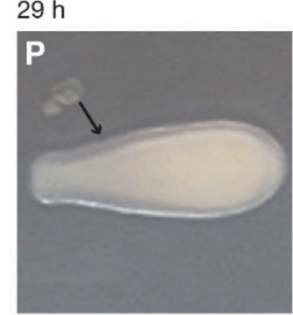

$61 \mathrm{~h}$

7 days

37 days

Fig. 1. Embryonic and larval development of Orbicella faveolata. Dissecting microscope images of A. spawned egg, B, heart-shaped embryo undergoing first cleavage, C. 2-cell embryo, D. 4-cell embryo, E. 8-cell embryo, and F. 16-32-cell embryo. G. The embryo has flattened, and blastocoel has formed. H-I. The embryo takes a cushion-shape form with a concavity when the pseudo-blastopore (+) is forming. J. The embryo becomes more spherical, without evidence of the pseudo-blastopore. K. The invagination of the blastopore $\left(^{*}\right)$ has begun. $\mathbf{L}$. The blastopore forms a major depression as the embryo regains its spherical shape. M. Early planula with oral pore (*). N. The early planula gradually elongates, and the translucent ectoderm is differentiated from the cream- colored central endoderm. O. Elongated planula larva. P. Planula larva with an evident ectoderm Q. Settled polyp with no zooxanthella R. Settled polyps with zooxanthella. This figure was done with pictures taken between the years 2018 and 2019. Photo credit: A, C, G, Q, R (Zárate-Arévalo); O, P, (Gómez-Lemos); J-M (Valcárcel) and the remaining (Hernández-Chamorro). 
under the dissecting microscope to quantify the survival of recruits over a period of 45 days. The seawater temperature in the flow-through tank was $29 \pm 0.4{ }^{\circ} \mathrm{C}$, the salinity $36 \pm 1.6$ and water flow $0.056 \pm 0.018 \mathrm{~L} / \mathrm{s}$ (mean $\pm \mathrm{SD}$ ). The post-settlement survival survey was conducted during October 2018.

Data analysis: For the settlement experiment one-way ANOVA, followed by multiple range tests with Fisher LSD method (Least Significant Difference), was used to test for differences among treatments. Data were checked for normality using a Shapiro-Wilk test and for homogeneity of variance using a Levene's test. Assumptions of normality and homogeneity of variance were not attained initially; therefore, data were Arc-sin transformed (Underwood, 1997). Statistical analyses were performed using Statgraphics (Centurion XVII).

\section{RESULTS}

Spawning observations: Spawning was observed 3.22-3.43 $\mathrm{h}$ after sunset on the sixth day after the full moon in September (2018 and 2019). Setting started by $21: 30 \mathrm{~h}$ and between 21:40 h-22:25 h we observed colonies spawning, with a peak from 21:50 h to 22:00 h. Spawning was only observed on the sixth day after full moon in September for logistic reasons, thus we cannot assure that spawning does not take place on the seventh day after full moon.

Embryogenesis: After fertilization, viable eggs were buoyant and spherical (Fig.1A). The first cleavage, 1 hour after fertilization, was equal and holoblastic and initiated at the animal pole forming a heart-shaped embryo (Fig. 1B), which resulted in two identical blastomeres (Fig. 1C). Second cleavage occurred approximately $1.5 \mathrm{~h}$ after the first cleavage, producing an embryo of 4 cells (Fig. 1D). Cell divisions progressed and between 2-7 $\mathrm{h}$ after the first cleavage embryos reached an 8 to 32 cell blastomere stage and acquired an irregular shape (Fig. 1E, Fig. 1F). $8.5 \mathrm{~h}$ after first cleavage embryos gradually showed a flattened and hollow spherical shape due to the formation of the blastocoel (Fig. 1G). After $30 \mathrm{~min}$, the first invagination, the "pseudo-blastopore" appeared on one side and became deeper, forming a cushion-shaped embryo (Fig. 1H, Fig. 1I). 10.5-16 $\mathrm{h}$ after first cleavage the pseudo-blastopore gradually disappeared, and the embryo became bowl-shaped (Fig. 1J). Approximately $16.5 \mathrm{~h}$ after first cleavage, the initial swimming was observed as weak and horizontal movement by some embryos. Simultaneously and until $19 \mathrm{~h}$ after first cleavage, a second concavity, the invagination of the blastopore appeared (Fig. 1K), which $10 \mathrm{~h}$ later became deeper (Fig. $1 \mathrm{~L})$. For the next hours, the embryos started elongating (Fig. 1M), and by $41 \mathrm{~h}$ after first cleavage, attained an early planula shape, the blastopore began to reduce in size (Fig. 1N). $55 \mathrm{~h}$ after the first cleavage, larvae displayed exploratory swimming (Fig. 1O, Fig. 1P). Larvae became competent to settle 7 days after the first cleavage, metamorphosing into translucent (no zooxanthellae) polyps (Fig.1Q). Finally, about 37 days after first cleavage, most polyps acquired zooxanthellae (Fig. 1R).

In summary, the process from assisted fertilization to settlement of larvae took 7 days in laboratory conditions (Table 1). $56 \mathrm{~h}$ after assisted fertilization embryogenesis was completed and the early planula phase started. Within 4 more days larvae started to settle.

Larval settlement: Larvae of $O$. faveolata had significantly different percentages of total settlement in response to several species of crustose coralline algae (ANOVA, $\mathrm{F}=2.38$, $\mathrm{P}=0.0393$ ). Larval settlement was higher in the presence of Lythophyllum congestum and Titanoderma prototypum than in response to Porolithon pachydermum, Neogoniolithon sp., Hydrolithon sp., and Lythophyllum sp. (multiple range tests with Fisher LSD method) (Fig. 2 ). Larvae only settled directly on the algal tissue in $T$. prototypum. Larvae did not settle on dead coral or in the negative control (sterilized seawater) (Fig. 2). 
TABLE 1

Timing for embryogenesis and larval development of Orbicella faveolata in laboratory conditions (2019)

\begin{tabular}{lcc}
\multicolumn{1}{c}{ Embryonic and larval stages } & Date & Time of day \\
Assisted fertilization & September 19, 2019 & $23: 30$ \\
First division & September 20, 2019 & $00: 32-00: 37$ \\
Four-blastomere stage & & $02: 00-02: 30$ \\
Morula & & $08: 12$ \\
First invagination-blastula & & $08: 30$ \\
Round-shaped & & $12: 00-18: 30$ \\
Second invagination - gastrula & September 21, 2019 \\
Pear-shaped & September 22, 2019 & $19: 00-23: 00$ \\
Planula (Larval stage) & September 26, 2019 & $20: 37$ \\
Settlement (Late planula) & & $08: 00$ \\
\hline
\end{tabular}

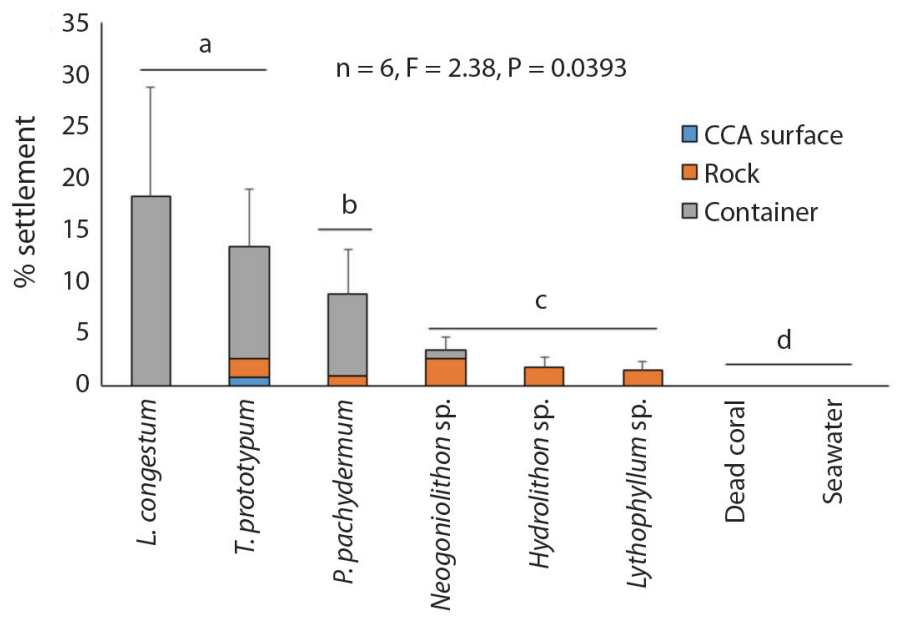

Fig. 2. Larval settlement patterns of Orbicella faveolata in response to different crustose coralline algal species. Bars represent mean for each treatment and error bars are standard deviation. Letters above the bars indicate significant groupings.

Post-settlement survival: After the first week, the percentage of survival was $59 \%$. Subsequently, survival decreased to $42 \%$ during the second week, and there was a marked decline in survival towards the third week (2 $\%)$. By the end of the third week there were no survivors on the settlement tiles (Fig. 3).

\section{DISCUSSION}

Embryogenesis: As expected for a "robust coral" after the morula stage, the embryos of $O$. faveolata underwent the development of a blastula stage, an early gastrula with no sign of pseudo-blastopore and a late gastrula with the blastopore. Later, a pear-shaped planula larva developed, and swimming behavior was observed. This observation is consistent with the general pattern reported by Okubo et al. (2013) and in general for Cnidaria (Campbell, 2012). Nevertheless, when comparing embryo development timing with different "robust corals" in the Merulinidae family, we found that the closer the species are in phylogeny (Kitahara, Fukami, Benzoni, \& Huang, 2016), the more similar the timing in embryogenesis is. For instance, timing in every embryonic 


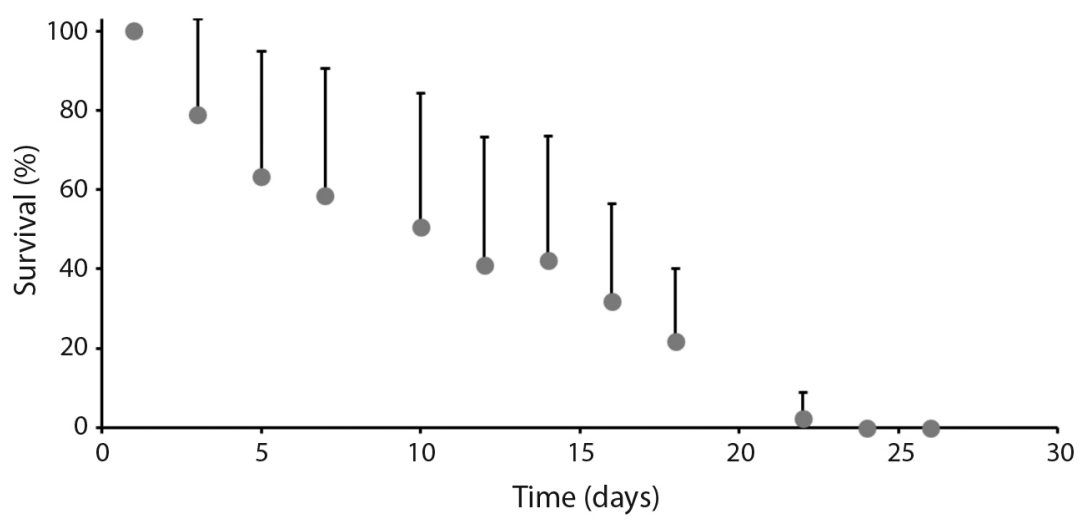

Fig. 3. Post-settlement survival of new recruits on settlement tiles under controlled conditions. Circles represent the mean percent survival of coral recruits and error bars are standard deviation.

stage for Goniastrea favulus, is closer to $O$. faveolata, than timing for Platygyra contorta or Favites abdita (Okubo et al., 2013). For Diploria labyrinthiformis, a member of Mussidae, which is also a "robust coral", differences are found since the earliest stages (Chamberland et al., 2016). Development occurs faster in D. labyrinthiformis; within 14 hours planula are swimming to the bottom, compared to 55 hours needed by $O$. faveolata to display a similar behavior. However, when comparing with species of the "complex corals" like Acropora spp. or Montipora spp. (Okubo et al., 2013) and A. cervicornis (Calle-Triviño et al., 2018), differences in timing are marked at the transition between embryos and planula. While in the "robust corals" this happens between 16 and 20 hours after the first cleavage, in "complex corals" occurs between 33 and 57 hours. Therefore, when comparing the minimal information available on other early life stages of coral species, it seems that from first cleavage to early gastrula, most species, regardless of being robust or complex, tend to show similar timing. Yet after this stage robust corals develop planula in shorter time than complex corals.

Larval settlement: Crustose coralline algae (CCA) species used in this study induced different percentages of settlement in coral larvae of $O$. faveolata. Two of the three CCA species that induced the highest settlement,
L. congestum and P. pachydermum, are abundant in shallow and luminous places in the study area, while $T$. prototypum is less abundant and is usually found in areas receiving less light, underneath coral rubble and in crevasses (Bula-Meyer, 1986; Bula-Meyer, DíazPulido, \& Celis, 1993). Therefore, O. faveolata can potentially recruit at least in two distinct environments in the area of study. Our results are consistent with the preferences previously found for this coral, with $T$. prototypum and $P$. pachydermum inducing more settlement than the majority of other CCA species (RitsonWilliams, Arnold, Paul, \& Steneck, 2014), except by $L$. congestum, however, there is no published information about $O$. faveolata settlement on this CCA species. In our study, only $T$. prototypum induced settlement directly on the living tissue (epithallus). The remaining CCA species induced settlement on the rock substrata and on the experimental container. This pattern can be explained based on the characteristics of the morphogens present in Titanoderma spp. Recent research has shown that morphogens produced by Titanoderma spp. are hydrophobic, and larvae must establish direct contact with the CCA surface to sense the cues and be induced to settle (GómezLemos et al., 2018). No settlement occurred on the surface of dead coral fragments, suggesting that benthic biofilms are not as important as CCA to prompt settlement of $O$. faveolata 
larvae. Various studies have shown that corals, that brood or spawn their offspring, are induced to settle by contact with CCA thalli (Morse \& Morse, 1991; Morse et al., 1996; Harrington, Fabricius, De'Ath, \& Negri, 2004) or in response to microbial biofilms (Webster et al., 2004; Cawa \& Hadfield, 2011; Siboni et al., 2012). However, spawning corals appear more selective than brooders, usually preferring CCA over biofilmed surfaces (Baird \& Morse, 2004; Ritson-Williams, Arnold, \& Paul, 2016), and our results confirm this trend. Finally, no settlement occurred in the negative control (sterilized seawater without CCA and without bacteria), confirming that $O$. faveolata larvae need cues from CCA to settle.

Early post-settlement survival: Coral recruitment is a complex process with three main stages: larval availability, larval settlement and post-settlement ecology (Pineda, Reyns, \& Starczak, 2009; Ritson-Williams et al., 2009), with each stage having a bottleneck. However, post-settlement survival is the most severe bottleneck, due to the minute size and high mortality of newly settled larvae (Gosselin \& Qian, 1997). Our research with $O$. faveolata is consistent with the tendency of high post-settlement mortality in corals. This mortality can be attributed mainly to competition for space with other benthic organisms inhabiting the settlement tiles. The tiles used in our experiment were deployed in the reef for one year, allowing enough time for the development of a diverse benthic community, including competitors such as filamentous algal turfs (19 $\pm 5 \%$ of cover). Algal turfs often accumulate sediments, and sediments are known to inhibit settlement and reduce post-settlement survival (Birrell, McCook, Willis, \& Diáz-Pulido, 2008). Although little is known about the chemical effects of algae on coral recruitment, it is been suggested that allelopathy by filamentous alga can kill Porites tissue (Jompa \& McCook, 2003a, 2003b) and cause larval mortality of Pocillopora acuta (Fong et al., 2019). Miller (2014) observed between 0 and $46 \%$ survivorship for O. faveolata settlers over 5-6 weeks in a field environment (this was on less-colonized substrates compared to our study). Other studies in laboratory-controlled conditions have found survival ranging from 0 to $70 \%$ one month after settlement, and high mortality has been mainly attributed to overgrowth and chemical deterrents from algae (Harrington et al., 2004). Therefore, negative effects of turf algae on settlers of $O$. faveolata may be the main reason of mortality in our study.

Final remark: Successful recruitment requires the survival of coral offspring through sequential life history stages (Ritson-Williams et al., 2009), i.e., larval availability, settlement, and post-settlement survival and growth of the new individual must be successful. Increased larvae availability is possible through assisted fertilization in laboratory conditions and our study conducted over three years (2016, 2018 and 2019) has demonstrated this and given necessary methods to enhance larvae availability, however, the bottleneck continues to be early post-settlement survival. Considering the high mortality in early post-settlement phases, much work has to be done for scaling up larvae production. In the present study, by the end of the first week more than $50 \%$ of settlers were alive, however, mortality rapidly increased in the following weeks. Specifically, by the end of the third week there was $100 \%$ mortality amongst $O$. faveolata reared under controlled conditions. When comparing these findings to those of Szmant and Miller (2006), corals reared in the field had 5-15\% survival after the first month, and 0-2\% by the second month. In a study over a five-year period, recruits deployed for 40-60 days in the field on racks with biofilm and minimal algae, had zero survival in some years and $47 \%$ in another year (Miller, 2014). More over survivorship beyond nine months is said to be extremely rare, thus for a successful recruitment rate to occur, efforts should be done for: 1) a very high initial settlement (Szmant \& Miller, 2006), and 2) improving our knowledge and understanding of those cues that enhance settlement and those that prevent or inhibit recruit survival. 
Even though this is a long-lived species and its life history reproductive strategy theoretically does not need a high production of offspring, due to the high partial mortality rate of adult colonies caused by disease and bleaching, and a changing environment for early life stages where fertilization and embryogenesis occurs, its survival is compromised and active restoration must take place.

Ethical statement: authors declare that they all agree with this publication and made significant contributions; that there is no conflict of interest of any kind; and that we followed all pertinent ethical and legal procedures and requirements. All financial sources are fully and clearly stated in the acknowledgements section. A signed document has been filed in the journal archives.

\section{ACKNOWLEDGMENTS}

We wish to thank E. Zarza, A. Reyes, A. Devia for photography of embryogenesis in one of the years, D. Duque, C. Olarte (PNNCRSB), A. Henao, M. Marrugo, L. Londoño (PNNCP), P. Pinzon (CEINER), C. Muñoz (ECOMARES), J. Prussman A. Rojas, I.A. Caicedo T., L. Pulecio, V. Jiménez and so many divers that helped collecting gamete bundles. C.A Martinez and S. Pauwels as directors of the Natural National Park Los Corales del Rosario y de San Bernardo gave us permissions and all the logistic support with boats and accommodation. R. Vieira, director of CEINER allowed us the use of laboratories and accommodation, B. Ossa, A. Obregon, J. Herrera (Diving Planet) for their diving facilities and company in the underwater work and Tessa $\mathrm{M}$. Page for providing insightful comments and edits to this manuscript.

\section{RESUMEN}

Historia de vida temprana del coral caribeño Orbicella faveolata (Scleractinia: Merulinidae). Introducción: La rehabilitación de las especies de corales hermatípicos del Caribe que han disminuido en las últimas décadas es una prioridad. La producción de reclutas sexuales se considera el mejor método de restauración para ayudar a las poblaciones afectadas. Objetivo: Obtener conocimiento de las primeras etapas de la vida de O. faveolata y mejorar la producción de nuevos reclutas sexuales. Métodos: Por dos años (2018 y 2019), seis días después de luna llena en septiembre, se recolectaron paquetes gaméticos en arrecifes del Parque Nacional Natural Los Corales del Rosario y de San Bernardo, Cartagena, Colombia. Se siguió la fertilización asistida, la cría de larvas, el asentamiento y la supervivencia posterior al asentamiento en algas coralinas costrosas (ACC) en condiciones de laboratorio. Resultados: El desarrollo de embriones y larvas se documenta a lo largo de $55 \mathrm{~h}$ después del primer clivaje, cuando la larva está desarrollada completamente y comenzó el comportamiento previo al asentamiento. El asentamiento comienza 7 días después del primer clivaje y 37 días después, la mayoría de los pólipos presentan zooxantelas. El asentamiento larval fue más alto en Lythophyllum congestum y Titanoderma prototypum que en respuesta a Porolithon pachydermum, Neogoniolithon sp., Hydrolithon sp., y Lythophyllum sp. No hubo asentamiento sobre coral muerto ni en el control negativo (agua de mar esterilizada). La supervivencia bajó de un $59 \%$ en la primera semana después del asentamiento, a $42 \%$ durante la segunda semana y $0 \%$ para el final de la tercera semana. Conclusiones: Las larvas de $O$. faveolata requieren señales de ciertas especies de ACC para asentarse, ellas no se asientan en ausencia de ACC. La disponibilidad de larvas es posible mediante la fertilización asistida en laboratorio. Sin embargo, debido a la alta mortalidad en las primeras fases posteriores al asentamiento, queda mucho por hacer para aumentar la producción de larvas y mejorar nuestro conocimiento y comprensión de las señales que mejoran el asentamiento y las que previenen o inhiben la supervivencia del recluta.

Palabras clave: desove; fertilización asistida; embriogénesis; asentamiento larval; post-asentamiento; algas coralinas costrosas.

\section{REFERENCES}

Alcolado, P.M., Valle, S., Claro, R., \& Hernández-Zanuy, A. (2016). Potenciando la resiliencia en los arrecifes coralinos en Cuba mediante la Adaptación Basada en Ecosistemas. La Habana, Cuba: Instituto de Oceanología. Recuperado de http:/www.cariberosos.org. ISBN978-959-298-037-2

Alvarado, E.M., Duque, F., Florez, L., \& Ramírez, R. (1986). Evaluación cuantitativa de los arrecifes coralinos de las Islas del Rosario (Cartagena-Colombia). Boletín Ecotrópica, 15, 1-30.

Alvarado, E., Pizarro, V., \& Sarmiento-Segura, A. (2011). Formaciones Arrecifales. In E. Zarza-González (Ed.), El entorno ambiental del Parque Nacional Natural 
Corales del Rosario y de San Bernardo (pp. 109123). Cartagena, Colombia: Parque Nacional Natural Corales del Rosario y de San Bernardo.

Baird, A.H., \& Morse, A.N.C. (2004). Induction of metamorphosis in larvae of the brooding corals Acropora palifera and Stylophora pistillata. Marine and Freshwater Research, 55, 469-472.

Bak, R., \& Meesters, E. (1999). Population Structure as a response of coral communities to global change. American Zoologist, 39(1), 56-65.

Birrell, C.L., McCook, L.J., Willis, B.L., \& Diaz-Pulido, G.A. (2008). Effects of benthic algae on the replenishment of corals and the implications for the resilience of coral reefs. Oceanography and Marine Biology, 46, 25-63.

Bozec, Y., Alvarez-Filip, L., \& Mumby, P. (2014). The dynamics of architectural complexity on coral reefs under climate change. Global Change Biology, 1-13. DOI: $10.1111 /$ gcb. 12698

Bula-Meyer, G. (1986). Las macroalgas de los arrecifes coralinos de las Islas del Rosario, costa Caribe de Colombia. Boletín Ecotrópica, 14, 3-20.

Bula-Meyer, G., Díaz-Pulido, G., \& Celis, A. (1993). Adiciones a las macroalgas de los arrecifes coralinos de las Islas del Rosario, con nuevos registros para el Caribe colombiano y el Atlántico. Anales del Instituto de Investigaciones Marinas de Punta Betín, 22, 21-29.

Burke, L., Reytar, K., Spalding, M., \& Perry, A. (2011). Reefs at Risk. Washington, USA: World Resources Institute.

Calle-Triviño, J., Cortés-Useche, C., Sellares-Blasco, R.I., \& Arias-González, E. (2018). Assisted fertilization of threatened staghorn coral to complement the restoration of nurseries in Southeastern Dominican Republic. Regional Studies in Marine Science, 18, 129-134. DOI: 10.1016/j.rsma.2018.02.002

Campbell, R.D. (2012). Development. In L. Muscatine, \& H. Lenhoff (Eds.), Coelenterate Biology reviews and new perspectives (pp. 179-206). New York, United States of America: Academic Press, Inc.

Cawa, T., \& Hadfield, M.G. (2011). Larvae of Pocillopora damicornis (Anthozoa) settle and metamorphose in response to surface-biofilm bacteria. Marine Ecology Progress Series, 433, 85-96.

Chamberland, V.F., Snowden, S., Marhaver, K.L., Petersen, D., \& Vermeij, M.J.A. (2016). The reproductive biology and early life ecology of a common Caribbean brain coral, Diploria labyrinthiformis (Scleractinia: Faviinae). Coral Reefs, 36. DOI: 10.1007/ s00338-016-1504-2
Chamberland, V.F., Petersen, D., Guest, J.R., Petersen, U., Brittsan, M., \& Vermeij, M.J.A. (2017). New seeding approach reduces costs and time to outplant sexually propagated corals for reef restoration. Scientific Reports, 7(1), 1-12. DOI: 10.1038/ s41598-017-17555-Z

Díaz, J.M., Barrios, L.M., Cendales, M.H., Garzón-Ferreira, J., Geiser, J., López-Victoria, M., ... Zea, S. (2000). Áreas Coralinas de Colombia. Santa Marta, Colombia: Instituto de Investigaciones Marinas y Costeras-INVEMAR.

Edmunds, P.J., \& Elahi, R. (2007). The demographics of a 15-year decline in cover of the Caribbean reef coral Montastraea annularis. Ecological Monographs, 77(1), 3-18.

Edmunds, P.J., Steneck, R., Albright, R., Carpenter, R.C., Chui, A.P.Y., Fan, T.Y., ... \& Mitarai, S. (2015). Geographic variation in long-term trajectories of change in coral recruitment: a global-to-local perspective. Marine and Freshwater Research, 66(7), 609-622.

Farr, T.J., Broom, J., Hart, D., Neill, K., \& Nelson, W. (2009). Common coralline algae of northern New Zealand. An identification guide. Wellington, New Zealand: NIWA Wellington.

Fong, J., Lim, Z.W., Bauman, A.G., Valiyaveettil, S., Liao, L.M., Yip, Z.T., \& Tood, P.A. (2019). Allelopathic effects of macroalgae on Pocillopora acuta coral larvae. Marine Environmental Research, 151, 104745.

Garzón-Ferreira, J., Rodríguez-Ramírez, A., BejaranoChavarro, S., Navas-Camacho, R., \& Reyes-Nivia, C. (2001). Estado de los arrecifes coralinos. In G. Ospina-Salazar, \& A. Acero (Eds.), Informe de Estado de los Ambientes Marinos y Costeros en Colombia: Año 2001 (pp. 29-40). Medellín, Colombia: Servigráficas.

Gómez-Lemos, L.A., Doropoulos, C., Bayraktarov, E., \& Díaz-Pulido, G. (2018). Coralline algal metabolites induce settlement and mediate the inductive effect of epiphytic microbes on coral larvae. Scientific Reports, 8, 17557.

Gosselin, L.A., \& Qian, P.Y. (1997) Juvenile mortality in benthic marine invertebrates. Marine Ecology Progress Series, 146, 265-282.

Guest, J., Heyward, A.J., Omori, M., Iwao, K., Morse, A., \& Boch, C. (2010). Rearing coral larvae for reef rehabilitation. In A. Edwards (Ed.), Reef Rehabilitation manual (pp. 73-98). St. Lucia, Australia: The Coral Reef Targeted Research \& Capacity Building for Management Program.

Guest, J.R., Baria, M.V, Gomez, E.D., Heyward, A.J., \& Edwards, A.J. (2014). Closing the circle: is it feasible to rehabilitate reefs with sexually propagated corals? Coral Reefs, 33, 45-55. DOI:10.1007/ s00338-013-1114-1 
Harrington, L., Fabricius, K., De'Ath, G., \& Negri, A. (2004). Recognition and selection of settlement substrata determine post-settlement survival in corals. Ecology, 85, 3428-3437.

Harrison, P. (2011). Sexual reproduction of Scleractinian corals. In Z. Dubinsky, \& N. Stambler (Eds.), Coral reefs: an ecosystem in transition (pp. 59-85). New York, USA: Springer. DOI: 10.1007/978-94-007-0114-4

Henao, A. (2012). Efecto de los aportes del canal del Dique sobre el reclutamiento de especies de coral en los arrecifes del archipiélago de Nuestra Señora del Rosario, Area Marina Protegida (Tesis de maestría). Universidad Jorge Tadeo Lozano, Bogotá, Colombia.

Heyward, A.J., \& Negri, A.P. (1999). Natural inducers for coral larval metamorphosis. Coral Reefs, 18, 273-279.

Hughes, T.P., \& Tanner, J.E. (2000). Recruitment failure, life histories, and long-term decline of Caribbean corals. Ecology, 81(8), 2250-2263.

Jompa, J., \& McCook, L.J. (2003a). Contrasting effects of turf algae on corals: massive Porites spp. are unaffected by mixed-species turfs but are killed by the red alga Anotrichium tenue. Marine Ecology Progress Series, 258, 79-86.

Jompa, J., \& McCook, L.J. (2003b). Coral-algal competition: macroalgae with different properties have different effects on corals. Marine Ecology Progress Series, 258, 87-95.

Kitahara, M.V., Fukami, H., Benzoni, F., \& Huang, D. (2016). The New Systematics of Scleractinia: Integrating Molecular and Morphological Evidence. In S. Goffredo, \& Z. Dubinsky (Eds.), The Cnidaria, Past, Present and Future: The world of medusa and her sisters (pp. 41-59). Gewerbestr, Switzerland: Springer International Publishing. DOI: 10.1007/978-3-319-31305-4

Lin, M., Kitahara, M.V., Luo, H., Tracey, D., Geller, J., Fukami, H., ... Chen, C.A. (2014). Mitochondrial Genome Rearrangements in the Scleractinia/ Corallimorpharia Complex: Implications for Coral Phylogeny. Genome Biology and Evolution, 6(5), 1086-1095. DOI: 10.1093/gbe/evu084

Littler, D.S., \& Littler, M.M. (2000). Caribbean reef plants: An identification guide to the reef plants of the Caribbean, Bahamas, Florida and Gulf of Mexico. Washington, USA: OffShore Graphics Inc.

Marhaver, K., Chamberland, V., \& Fogarty, N. (2017). Caribbean Coral Spawning for Research and Restoration: How to raise larvae and outplant settlers without shedding (a lot of) blood and tears. Curacao, Netherlands: NOAA/TNC Coral Restoration Webinar presented on 8 February 2017.

Miller, M.W., Weil, E., \& Szmant, A.M. (2000). Coral recruitment and juvenile mortality as structuring factors for reef benthic communities in Biscayne National Park, USA. Coral Reefs, 19, 115-123.

Miller, M.W. (2014). Post-settlement survivorship in two Caribbean broadcasting corals. Coral Reefs, 33, 1041-1046. DOI: 10.1007/s00338-014-1177-7

Morse, D.E., \& Morse, A.N.C. (1991). Enzymatic characterization of the morphogen recognized by Agaricia humilis (scleractinian coral) larvae. Biological Bulletin, 181, 104-122.

Morse, A.N.C., Iwao, K., Baba, M., Shimoike, K., Hayashibara, T., \& Omori, M. (1996) An ancient chemosensory mechanism brings new life to coral reefs. Biological Bulletin, 191, 149-154.

Nakamura, M., Ohki, S., Suzuki, A., \& Sakai, K. (2011). Coral Larvae under Ocean Acidification: Survival, Metabolism, and Metamorphosis. PLoS One, 6(1), e14521. DOI: 10.1371/journal.pone.0014521

Navas-Camacho, R., Gómez-Campo, K., Vega-Sequeda, J., \& López-Londoño, T. (2009). Estado de los Arrecifes Coralinos. In INVERMAR (Ed.), Informe de Estado de los Ambientes y Recursos Marinos y Costeros en Colombia Año 2008 (pp. 59-88). Santa Marta, Colombia: Instituto de Investigaciones Marinas y costeras-INVEMAR.

Okamoto, M., Nojima, S., Fujiwara, S., \& Furushima, Y. (2008). Development of ceramic settlement devices for coral reef restoration using in situ sexual reproduction of corals. Fisheries Science, 74, 1245-1253. DOI: 10.1111/j.1444-2906.2008.01649.x

Okubo, N., Mezaki, T., Nozawa, Y., Nakano, Y., Lien, Y., Fukami, H., ... Ball, E.E. (2013). Comparative Embryology of Eleven Species of Stony Corals (Scleractinia). PLOS ONE, 8(12), 1-22. DOI: 10.1371/journal. pone. 0084115

Omori, M. (2005). Success of mass culture of Acropora corals from egg to colony in open water. Coral Reefs, 24, 563. DOI:10.1007/s00338-005-0030-4.

Pineda, J., Reyns, N.B., \& Starczak, V.R. (2009). Complexity and simplification in understanding recruitment in benthic populations. Population Ecology, 51, 17-32.

Restrepo, J.D., \& Kjerfve, B. (2000). Magdalena river: interannual variability (1975-1995) and revised water discharge and sediment load estimates. Journal of Hydrology, 235, 137-149.

Restrepo, J.D., \& Alvarado, E.M. (2011). Assessing major environmental issues in the Caribbean and Pacific coasts of Colombia, South America: An overview of fluvial fluxes, coral reef degradation, and mangrove ecosystems impacted by river diversion. In E. Wolansky \& D. McLusky (Eds.), Treatise on Estuarine and Coastal Science (pp. 289-314). Waltham, USA: Academic Press. DOI: 10.1016/ B978-0-12-374711-2.01117-7 
Restrepo, J.D, Park, E., Aquino, S., \& Latrubesse, E.M. (2016). Coral reefs chronically exposed to river sediment plumes in the Southwestern Caribbean: Rosario Islands, Colombia. Science of the Total Environment, 553, 316-329. DOI: 10.1016/j.scitotenv.2016.02.140

Ritson-Williams, R., Arnold, S.N., Fogarty, N.D., Steneck, R.S., Vermeij, M.J., \& Paul, V.J. (2009). New perspectives on ecological mechanisms affecting coral recruitment on reefs. Smithsonian Contributions to Marine the Sciences, 38, 437-457.

Ritson-Williams, R., Arnold, S.N., Paul, V.J., \& Steneck, R.S. (2014). Larval settlement preferences of Acropora palmata and Montastraea faveolata in response to diverse red algae. Coral Reefs, 33, 59-66.

Ritson-Williams, R., Arnold, S.N., \& Paul, V.J. (2016). Patterns of larval settlement preferences and postsettlement survival for seven Caribbean corals. Marine Ecology Progress Series, 548, 127-138.

Sánchez, J.A., Alvarado, E.M., Gil, M.F., Charry, H., Arenas, O.L., Chasqui, L.H., \& Rocio, P. (1999). Synchronous mass spawning of Montastraea annularis (Ellis \& Solander) and Montastraea faveolata (Ellis \& Solander) (Faviidae: Scleractinia) at Rosario islands, Caribbean coast of Colombia. Bulletin of Marine Science, 65(3), 873-879.

Siboni, N., Abrego, D., Seneca, F., Motti, C., Andreakis, N., Tebben, J., ... Harder, T. (2012). Using bacterial extract along with differential gene expression in Acropora millepora larvae to decouple the processes of attachment and metamorphosis. PLoS One, 7, e37774.

Solano, O.D., Navas, G., \& Moreno-Forero, S. (1993). Blanqueamiento coralino de 1990 en el Parque Nacional Natural Corales del Rosario (Caribe, colombiano). Anales del Instituto de Investigaciones Marinas de Punta Betín, 22, 97-111.

Szmant, A., \& Miller, M. (2006). Settlement preferences and post-settlement mortality of laboratory cultured and settled larvae of the Caribbean hermatypic corals Montastraea faveolata and Acropora palmata in the Florida Keys, USA. Proceedings of 10th International Coral Reef Symposium. Okinawa Convention Center, Okinawa, Japan.

Taylor, W.R. (1960). Marine algae of the eastern tropical and subtropical coasts of the Americas. Michigan, USA: University of Michigan Press, Ann Arbor.

Underwood, A.J. (1997). Experiments in ecology: Their logical design and interpretation using analysis of variance. Cambridge, UK: Cambridge University Press.

Van Veghel, M.L.J., \& Bak, R.P.M. (1994). Reproductive characteristics of the polymorphic Caribbean reef building coral Montastrea annularis. III. Reproduction in damaged and regenerating colonies. Marine Biology Research, 109, 229-233.

Vermeij, M.J.A., Frade, P.R., Jacinto, R.I.R., Debrot, A.O., \& Bak, R.P.M. (2007). Effects of reproductive mode on habitat-related differences in the population structure of eight Caribbean coral species. Marine Ecology Progress Series, 351, 91-102. DOI: 10.3354/ meps07085.

Vermeij, M.J.A., Bakker, J., van der Hal, N., \& Bak, R.P.M. (2011). Juvenile Coral Abundance Has Decreased by More Than $50 \%$ in Only Three Decades on a Small Caribbean Island. Diversity, 3, 296-307. DOI: $10.3390 / \mathrm{d} 3030296$

Webster, N.S., Smith, L.D., Heyward, A.J., Watts, J.E.M., Webb, R.I., Blackall, L.L., ... \& Al, W.E.T. (2004). Metamorphosis of a scleractinian coral in response to microbial biofilms. Applied and Environmental Microbiology, 70(2), 1213-1221. DOI: https://doi. org/10.1128/AEM.70.2.1213

Williams, D.E., Miller, M.W., \& Kramer, K.L. (2008). Recruitment failure in Florida Keys Acropora palmata, a threatened Caribbean coral. Coral Reefs, 27(3), 697-705. 